\title{
PENERAPAN METODE FORWARD CHAINING PADA PERANCANGAN SISTEM PAKAR DIAGNOSIS AWAL DEMAM BERDARAH
}

\author{
${ }^{[1]}$ Sri Lestanti, ${ }^{[2]}$ Sabitul Kirom, dan ${ }^{[3]}$ Dini Kustiari

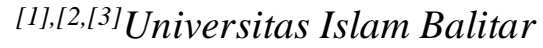

\begin{abstract}
Abstrak: Demam berdarah merupakan penyakit yang disebabkan oleh gigitan nyamuk Aedes aegypti betina yang terinfeksi oleh arboviruses, dan bersifat menular berbahaya. Dalam penyelesaiannya membutuhkan suatu alat yang dikenal sebagai sistem pakar. Sistem pakar ini yang akan membantu user mendiagnosis suatu penyakit serta memberikan pengetahuan yang dibutuhkan terkait penyakit demam berdarah. Aplikasi ini dibangun untuk diagnosis awal demam berdarah dengan menggunakan penerapan Metode Forward Chaining. Hasil dari pengujian menunjukkan aplikasi ini dapat digunakan secara efektif untuk mendiagnosis penyakit demam berdarah.
\end{abstract}

Kata kunci: Demam Berdarah, Metode Forward Chaining, Sistem Pakar

\section{Pendahuluan}

Forward Chaining adalah metode pencarian / penarikan kesimpulan yang berdasarkan pada data atau fakta yang ada menuju ke kesimpulan. Penelusuran dimulai dari fakta yang ada lalu bergerak maju melalui premis-premis untuk menuju ke kesimpulan / bottom up reasoning. Forward chaining melakukan pencarian dari suatu masalah kepada solusinya. Jika klausa premis sesuai dengan situasi, maka proses akan memberikan kesimpulan.

Demam berdarah merupakan penyakit yang disebabkan oleh gigitan nyamuk Aedes aegypti betina yang terinfeksi oleh arboviruses, dan bersifat menular berbahaya. Perjalanan penyakit akibat infeksi virus dengue sulit diprediksi. Biasanya pasien mengalami fase demam selama 2 sampai 7 hari yang diikuti oleh fase kritis demam selama 2 sampai 3 hari. Pada saat fase kritis ini, pasien biasanya sudah tidak mengalami demam, tetapi berpeluang untuk menuju ke Demam Berdarah Dengue (DBD) maupun Syndrom Shock Dengue yang dapat bermuara pada kondisi fatal jika tidak diberikan pengobatan yang adekuat. Kematian yang dialami pasien demam berdarah sebagian besar akibat terjadinya perdarahan dan shock. Apabila terjadi perdarahan atau shock maka harus segera diberikan pengobatan secara cepat dan tepat. Penetapan diagnosis secara tepat disertai dengan pengobatan yang akurat dapat menurunkan angka kematian akibat penyakit ini (Djunaedi, 2006). 
Berdasarkan data dari Dinas Kesehatan Kabupaten Blitar, pada bulan Januari hingga pertengahan bulan Maret 2016 ditemukan sebanyak 138 kasus penderita DBD dan lima orang di antaranya meninggal dunia. Lima orang tersebut berasal dari lima kecamatan yang berbeda di Kabupaten Blitar. Selain di Kabupaten Blitar, kasus DBD juga terjadi di Kota Blitar. Berdasarkan data dari Dinas Kesehatan Kota Blitar, diketahui bahwa sampai pada bulan Februari tercatat sebanyak 63 kasus penyakit DBD. Kasus penderita demam berdarah kebanyakan terjadi pada anak-anak. Selain itu, kasus penderita demam berdarah juga ditemukan pada orang dewasa.

Pemahaman masyarakat Kabupaten Blitar tentang bahaya DBD masih kurang. Pemahaman yang minim, mengakibatkan masyarakat menjadi kurang waspada akan bahaya yang ditimbulkan oleh nyamuk Aedes aegypti ini, sehingga masih ada saja warga yang jatuh sakit. Hal inilah yang juga membuat pasien cenderung mengalami keterlambatan penanganan. Bisa dipastikan jika terjadi keterlambatan penanganan, pasien akan mengalami fase sakit yang lebih parah atau berada pada kondisi fatal. Oleh karena itu, dibutuhkan suatu rancangan sistem pakar yang dapat membantu masyarakat atau pasien untuk mendiagnosis awal gejala demam berdarah.

Sistem pakar adalah sistem yang berusaha mengadopsi pengetahuan manusia ke komputer yang dirancang untuk memodelkan kemampuan menyelesaikan masalah seperti layaknya seorang pakar. Dalam penyusunannya, sistem pakar mengkombinasikan kaidah-kaidah penarikan kesimpulan atau inference rules dengan basis pengetahuan tertentu yang diberikan oleh satu atau lebih pakar dalam bidang tertentu. Kombinasi dari kedua hal tersebut disimpan dalam komputer, yang selanjutnya digunakan dalam proses pengambilan keputusan untuk penyelesaian masalah tertentu. (Turban, at al., 2005). Menurut Durkin (1994) komponen utama pada struktur sistem pakar meliputi Basis Pengetahuan / Knowledge Base, Mesin Inferensi / Inference Engine, Working Memory, dan Antarmuka Pemakai / User Interface.

\section{Metode Penelitian}

\section{A. Tempat dan Waktu Penelitian}

Penelitian ini dilaksanakan di Dusun Kaotan, Desa Jeding, Kecamatan Sanankulon Kabupaten Blitar. Adapun waktu pelaksanaannya dimulai dari bulan Januari sampai Juli 2017.

\section{B. Identifikasi Permasalahan}

Pada tahap ini dilakukan identifikasi terhadap permasalahan yang ada pada Dusun Kaotan, Desa Jeding, Kecamatan Sanankulon Kabupaten Blitar. Berdasarkan hasil wawancara yang dilakukan peneliti terhadap warga Dusun Kaotan, Desa Jeding, Kecamatan Sanankulon Kabupaten Blitar diketahui bahwa terdapat permasalahan yang berkaitan dengan kesehatan masyarakat di daerah tersebut. Permasalahn tersebut berkaitan dengan pemahaman masyarakat tentang bahaya DBD yang masih kurang. 
Pemahaman yang minim, mengakibatkan masyarakat di daerah tersebut menjadi kurang waspada akan bahaya yang ditimbulkan oleh nyamuk Aedes aegypti, sehingga masih ada saja warga yang jatuh sakit. Hal inilah yang juga membuat pasien cenderung mengalami keterlambatan penanganan. Jika terjadi keterlambatan penanganan maka tidak menutup kemungkinan pasien akan mengalami fase sakit yang lebih parah atau berada pada kondisi fatal. Oleh karena itu, dibutuhkan suatu rancangan sistem pakar yang dapat membantu masyarakat atau pasien untuk mendiagnosis awal gejala demam berdarah.

\section{Pengumpulan Data}

Pada tahap ini dilakukan pengumpulan informasi dan data yang diperlukan dalam penelitian. Data yang digunakan dalam penelitian ini adalah data yang berkaitan dengan penyakit DBD. Teknik pengumpulan data yang dilakukan dalam penelitian ini sebagai berikut.

\section{Studi Literatur}

Berupa pengumpulan informasi dan mempelajari materi serta sumber-sumber data yang diperlukan untuk membangun sistem yang berhubungan dengan penelitian ini. Literatur-literatur diambil dari penelitian sebelumnya maupun dari beberapa buku, skripsi, dan jurnal-jurnal ilmiah, baik dalam negeri maupun luar negeri.

\section{Wawancara}

Kegiatan wawancara dilakukan secara langsung (face to face) antara peneliti dengan masyarakat Dusun Kaotan, Desa Jeding, Kecamatan Sanankulon Kabupaten Blitar dan pakar kesehatan di bidang penyakit DBD. Tujuan wawancara tersebut untuk memperoleh data yang dapat menjelaskan ataupun menjawab suatu permasalahan dalam penelitian.

\section{Observasi}

Observasi dilakukan secara langsung oleh peneliti di Dusun Kaotan, Desa Jeding, Kecamatan Sanankulon Kabupaten Blitar. Observasi dilakukan untuk mendapatkan data yang akurat yang digunakan dalam penelitian.

\section{Perancangan Sistem}

\section{Flowchart}

Pada tahap ini dijelaskan mengenai perancangan sistem yaitu sebagai berikut.

Flowchart merupakan gambar atau bagan yang memperlihatkan urutan dan hubungan antar proses beserta instruksinya. Flowchart pada penelitian ini berupa Flowchart Sistem. Flowchart Sistem merupakan bagan yang menunjukkan alur kerja atau apa yang sedang dikerjakan di dalam sistem secara keseluruhan dan menjelaskan urutan dari prosedur-prosedur yang ada di dalam sistem. Flowchart Sistem dalam penelitian ini ditunjukkan pada gambar 1 . 


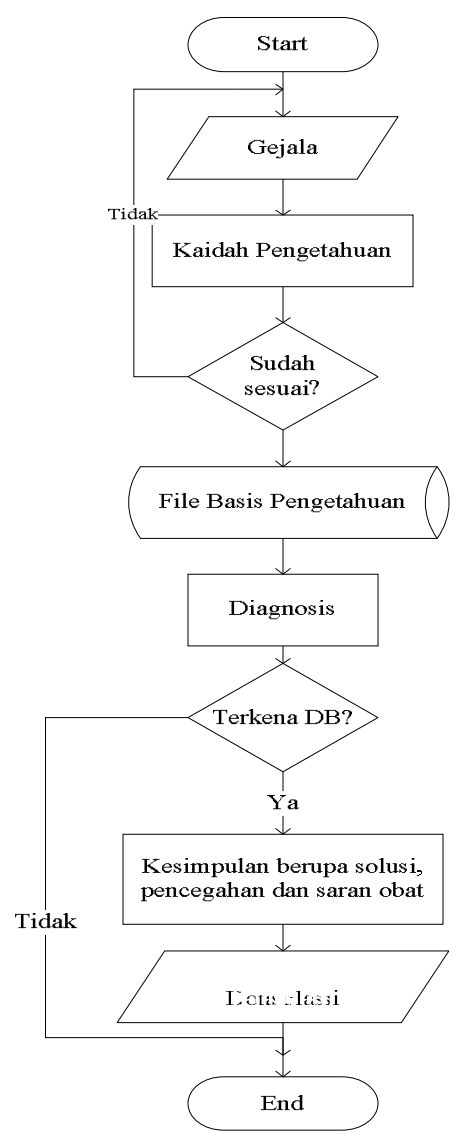

Gambar 1 Flowchart Proses Penalaran Sistem Pakar Diagnosis Awal Demam Berdarah menggunakan Foward Chaining

\section{Data Flow Diagram (DFD)}

DFD merupakan salah satu cara untuk memodelkan proses dalam analisis dan perancangan perangkat lunak. DFD perancangan sistem yang akan dibangun pada penelitian ini dapat ditunjukan pada gambar 2 dan 3 berikut. 
(a) Data Flow Diagram Level 0

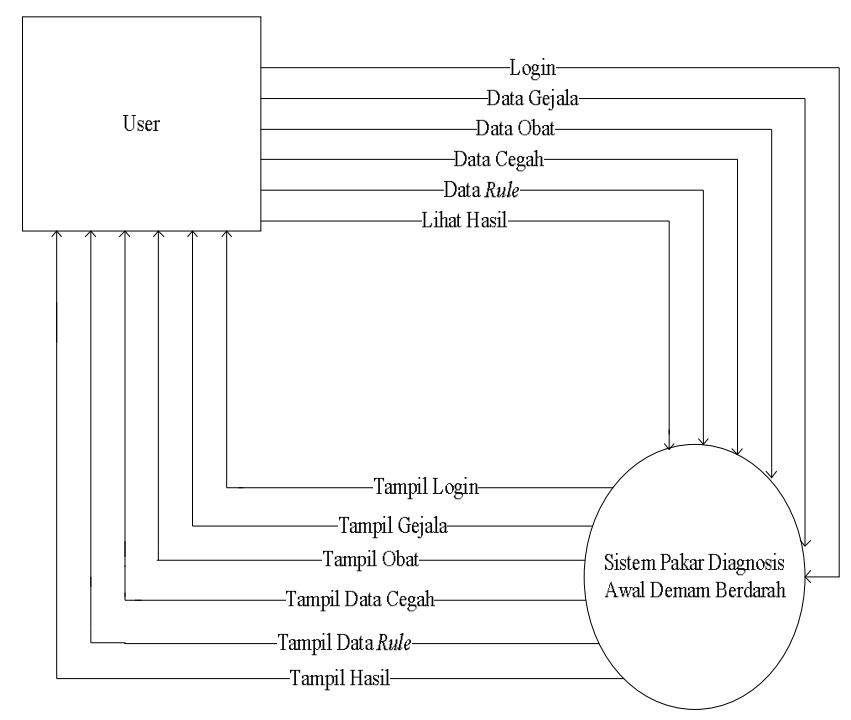

Gambar 2 DFD Level 0

Diagram konteks merupakan diagram yang terdiri atas suatu proses yang menggambarkan ruang lingkup suatu sistem. Diagram konteks adalah level yang paling tinggi dari Data Flow Diagram (DFD), yang menggambarkan keseluruhan input ke sistem dan output dari sistem.

\section{(b) Data Flow Diagram Level 1}

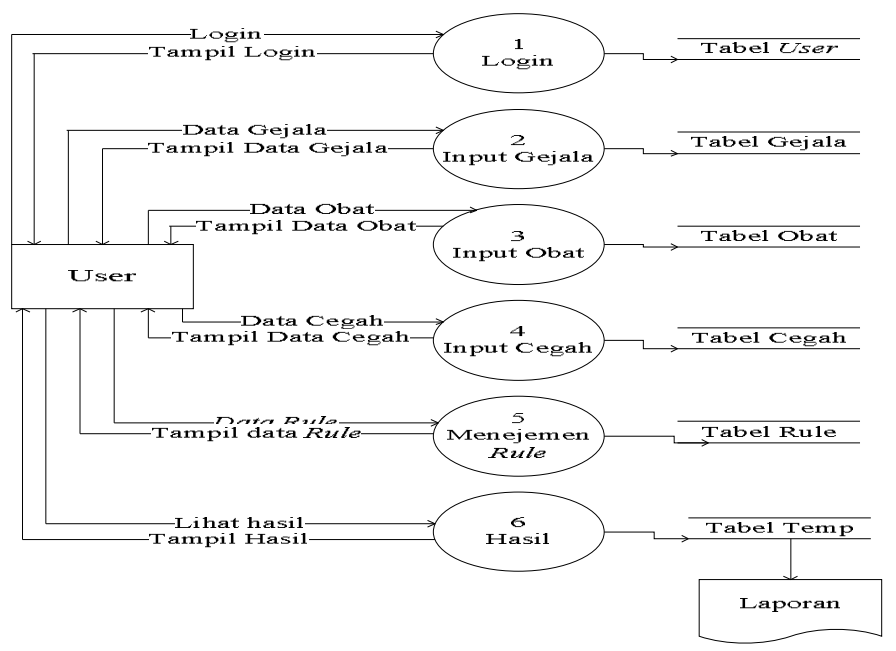

Gambar 3 DFD Level 1 
Pada diagram tersebut dijelaskan jenis proses dalam sistem. Level ini terdapat 6 proses yang bersesuaian dengan fungsi dari setiap halaman yang ada dan mampu menyimpan hasilnya dalam database.

\section{(c) Entity Relational Diagram}
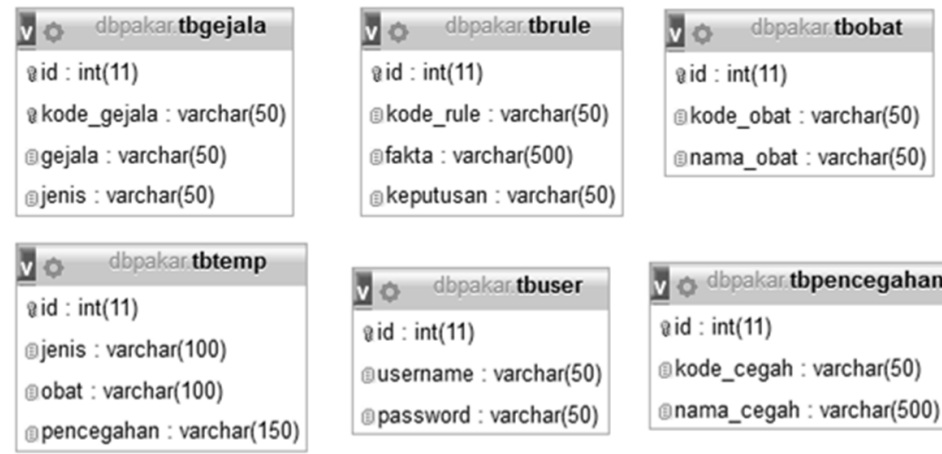

vo dbpakar tbpencegahan
จid : int(11)
okode_cegah : varchar(50)
enama_cegah : varchar(500)

Gambar 4 Entity Relational Diagram

Keterangan dari gambar 4 tersebut sebagai berikut. Pada Entity Relational Diagram dijelaskan semua tabel yang akan digunakan pada sistem pakar diagnosis awal demam berdarah.

\section{Hasil dan Pembahasan}

\section{A. Implementasi Sistem}

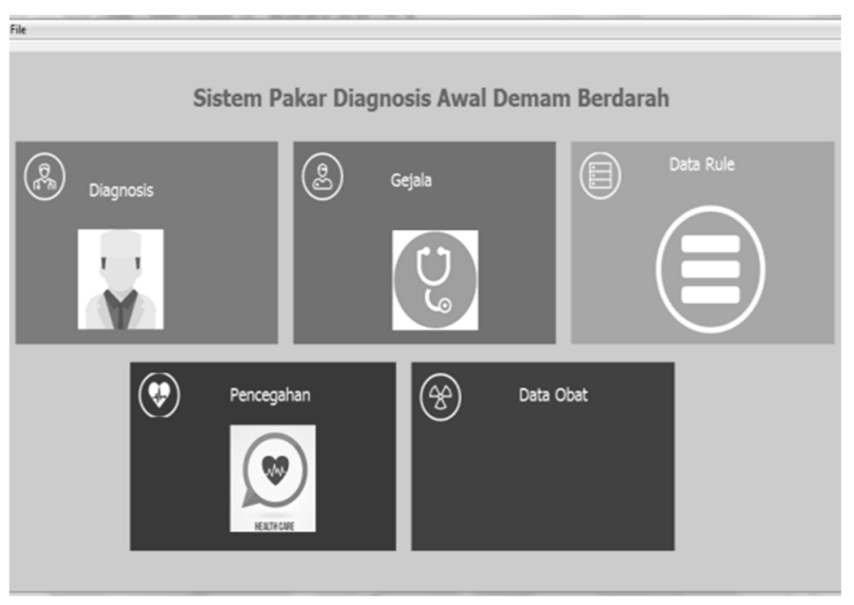

Gambar 4 Halaman Utama 


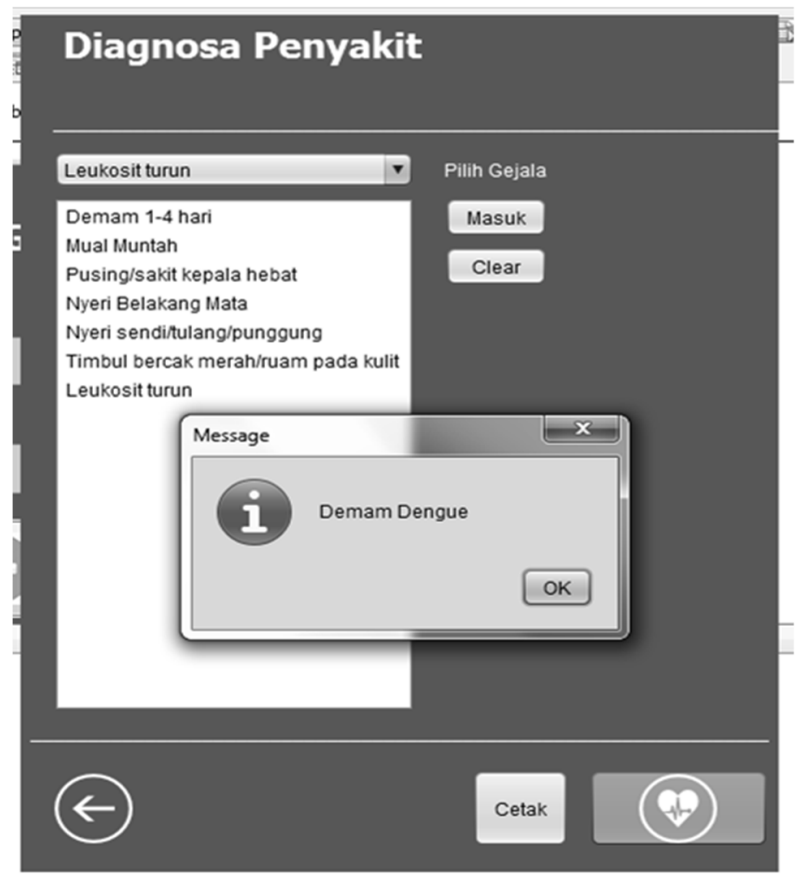

Gambar 5 Halaman Diagnosis Penyakit

\section{B. Pengujian Sistem}

Pengujian sistem ini menggunakan kuisioner yang disebarkan kepada responden. Responden dalam penelitian ini adalah ibu-ibu PKK dan kelompok tani di Dusun Kaotan, Desa Jeding, Kecamatan Sanankulon, Kabupaten Blitar. Keterangan nilai yang digunakan sebagai berikut. "SS" adalah "Sangat Setuju", "S" adalah "Setuju", "KS" adalah "Kurang Setuju", dan "TS" adalah "Tidak Setuju".

(1) Rekapitulasi Desain Sistem

Nilai total aspek desain sistem $=2940$

1. $\mathrm{SS}=1000 / 2940 \times 100 \%=34,01 \%$

2. $\mathrm{S}=1430 / 2940 \times 100 \%=48,63 \%$

3. $\mathrm{KS}=500 / 2940 \times 100 \%=17,00 \%$

4. $\mathrm{TS}=10 / 2940 \times 100 \%=0,34 \%$

(2) Rekapitulasi Kesesuaian sistem

Nilai total aspek kesesuaian sistem $=3050$

1. $\mathrm{SS}=1000 / 3050 \times 100 \%=32,78 \%$

2. $\mathrm{S}=1580 / 3050 \times 100 \%=51,80 \%$

3. $\mathrm{KS}=460 / 3050 \times 100 \%=15,08 \%$

4. $\mathrm{TS}=10 / 3050 \times 100 \%=0,32 \%$ 
(3) Rekapitulasi Kemudahan Sistem

Nilai total aspek kemudahan sistem $=2700$

$$
\begin{array}{lll}
\text { 1. } & \mathrm{SS}=1000 / 2700 \times 100 \% & =37,00 \% \\
\text { 2. } & \mathrm{S}=1290 / 2700 \times 100 \% & =47,78 \% \\
\text { 3. } & \mathrm{KS}=400 / 2700 \times 100 \% & =14,81 \% \\
\text { 4. } & \mathrm{TS}=10 / 2700 \times 100 \% & =0,37 \%
\end{array}
$$

Berdasarkan hasil dari pengujian tersebut diketahui bahwa pada bagian desain sistem sebanyak $48,63 \%$ menyatakan setuju dengan tampilan sistem pakar diagnosis awal demam berdarah ini. Indikasi ini menyatakan bahwa sistem pakar diagnosis awal demam berdarah memiliki tampilan antar muka yang menarik. Pada sub-bab kesesuaian sistem, sebanyak $51,80 \%$ responden menyatakan setuju dengan kesesuaian sistem pakar diagnosis awal demam berdarah ini. Sub-bab terakhir dalam responden ini adalah kemudahan sistem yakni berkaitan dengan mudah tidaknya user menggunakan sistem pakar ini. Sebanyak $47,78 \%$ responden menyatakan setuju dengan kemudahan sistem pakar diagnosis awal demam berdarah ini.

\section{A. Simpulan}

\section{SimPUlan DAN SARAN}

Berdasarkan permasalahan yang telah dibahas dan diselesaikan melalui laporan ini, maka kesimpulan dari penelitian ini sebagai berikut.

a. Sistem pakar diagnosis awal demam berdarah ini dibutuhkan masyarakat umum. Sistem ini dirancang dengan desain yang cukup menarik dan mempunyai menumenu yang mampu mendukung berlangsungnya proses diagnosis. Persesntase yang diraih pada kesesuaian sistem ini adalah sebesar 48,63\%. Angka ini menunjukkan bahwa responden menyetujui desain sistem pakar diagnosis awal demam berdarah.

b. Sistem pakar diagnosis awal demam berdarah yang telah dibuat melingkupi inovasi dengan memanfaatkan data di dalamnya. Metode Forward Chaining yang diimplementasikan dalam sistem ini mendapatkan respon sebesar 51,80\%. Dengan persentase perolehan tersebut, responden menyetujui kesesuaian sistem pakar diagnosis awal demam berdarah ini.

c. Penerapan sistem pakar ini dapat diakses menggunakan Personal Computer (PC) untuk dapat digunakan mendiagnosis awal demam berdarah. Sebanyak 47,78\% responden menyatakan setuju dengan kemudahan dalam penggunaan sistem ini.

\section{B. Saran}

Berikut beberapa saran untuk pengembangan lebih lanjut dari aplikasi ini.

c. Menu dan fitur pada aplikasi ini masih dapat ditambahkan dengan menu yang lain bergantung dari kebutuhan. 
d. Aplikasi ini dapat dikembangkan lagi, misalnya digunakan untuk penyakit yang lain.

\section{Daftar Pustaka}

Djunaedi, Dj. 2006. Demam Berdarah: Epidemologi, Immunopatologi, Patogenesis, Diagnosis, dan Penatalaksanaanya. Malang: UMM Press.

Durkin, J. 1994. Expert System Design and Development. London: Prentice Hall International Edition, Inc.

Satari, H. I. dan Mila M. 2005. Demam Berdarah Perawatan di Rumah dan Rumah Sakit. Puspa Swara: Jakarta.

Turban, E., Aronson, J.E., Ting, P.L., 2005. Decision Support System and Intelligent Systems (Sistem Pendukung Keputusan dan Sistem Cerdas) jilid 1. Yogyakarta: Andi. 